\title{
VIII
}

\section{THE INFLUENCE OF ARTIFICIALLY INDUCED FEVER UPON SYPHILITIC INFECTION OF MICE}

\author{
By A. BECK, Rockefeller Research Fellow
}

(From the Central Pathological Laboratory, L.C.C. Mental Hospitals

Department, and the Devonport Laboratory, Seamen's Hospital, Greenwich.)

Since Weichbrodt and Jahnel's (IgIg) first experiments on the action of artificially induced fever in rabbits infected with syphilis, the knowledge concerning the influence of heat on syphilis spirochætes has been extended and elucidated by numerous experimental observations. (Schamberg and Rule, I927; Bessemans, I928, I936; Carpenter, Boak and Warren, I932; Richet and Dublineau, I932 ; Levaditi and Rothschild, I934; Kolmer and Rule, I933). The main points resulting from this work may be summarised as follows: Artificially induced fever is able to prevent and heal open syphilitic lesions in animals, provided that a sufficient degree of heat is reached in the lesion itself. Whilst in external lesions spirochætes succumb relatively quickly (after one to two hours) to temperatures of $104^{\circ} \mathrm{F}$. to $108^{\circ} \mathrm{F}$., they resist much higher degrees of temperature $\left(\mathrm{II} 5^{\circ} \mathrm{F}\right.$. and even more) in the lymph-glands and thereby render the complete sterilisation of the syphilitic individual extremely difficult, if not impossible. The spirochætes in the brain of general paralytics seem to display a similar susceptibility to heat as the spirochætes in external lesions.

In the investigations quoted the amount of fever given to the animals was far less than that developed by general paralytics during a full course of malaria. Although it seemed to be quite sufficient for many of the conditions tested-especially for the sterilisation of external lesions -it is possible that a longer treatment might have killed spirochætes, especially those of the lymph system, which had survived the relatively short treatment. It therefore seemed of interest to examine whether better results 


\section{BRITISH JOURNAL OF VENEREAL DISEASES}

could be obtained with a type of fever following more closely the course of malaria fever.

For these experiments syphilis-infected mice were chosen for the following reasons : All previous investigations, except those of Levaditi and his collaborators, who also used mice, were made on rabbits in which the syphilitic infection is known to produce manifest lesions with an intense tissue reaction. This reaction might in itself, especially when stimulated by fever, form a part of the sterilising action of heat. The absence of any pronounced tissue reaction against the invading spirochætes in the mouse in which the syphilitic infection takes a latent course, seemed to render this animal especially apt for the study of the direct effect of heat on spirochætes. The mouse is, furthermore, one of the few animals in which the spirochætes invade the brain. Although they occur only scantily in this organ (Bessemans and de Moor, I937) and do not produce any lesions like those in the general paralytic, it was thought that the mouse might still serve to compare the heat resistance of spirochætes in the brain and in other organs. This comparison seemed to be of interest because clinical and serological experience in malaria-treated general paralytics suggested some difference in the susceptibility to heat between the two kinds of spirochætes. Thus after malarial treatment the W.R. in the cerebrospinal fluid returns more quickly to normal than the reaction in the blood. Furthermore, cases are known in which after an apparently successful malaria cure tertiary lesions have appeared (for literature see Dattner; I933).

\section{EXPERIMENTAL}

The mice used in these experiments were inoculated 58 to 460 days before the beginning of the fever treatment with chancre pieces from rabbits infected with the Nichols or Truffi strain. Fever was induced by exposing the mice to hot air in an insulated box. The source of heat was a carbon-filament lamp. The box contained four separate compartments allowing the simultaneous heating of four mice. A continuous and very careful control of the air temperature was necessary so as to maintain a high, even and tolerable fever during the whole session. In spite of this there were heavy losses of animals in each series of experiments as mice sustain fever badly. The 
greatest losses occurred during the first four to five sessions. Once this point was safely reached the animals stood further treatment well. The temperature of the mice was controlled rectally. Attempts to measure the intracranial temperature with a thermocouple proved impracticable, as the introduction of the thermoneedle into the brain was followed by shock and a rapid fall of temperature. I also desisted from measuring the temperature of the lymph glands or other organs thermoelectrically because the trauma produced by repeated puncturings might have acted indirectly upon the spirochætes.

The fever treatment was performed intermittently, in some experiments every day, in others every other day. In the first series of experiments an attempt was made to produce as high a fever as possible $\left(106^{\circ} \mathrm{F}\right.$ to $108^{\circ} \mathrm{F}$. and more). As mice could only sustain such an intense heat for a short time the duration of each session of heating was limited to fifteen minutes. With a high surrounding temperature $\left(110^{\circ} \mathrm{F}\right.$. to $116^{\circ} \mathrm{F}$.) the fever peak was rather quickly reached. In order to reveal any possible difference between brain and other spirochætes in their susceptibility to heat the number of heatings was varied, the longest course of treatment comprising twenty-five sessions, the shortest five sessions, the total duration of fever thus varying from one and a quarter.to six and a quarter hours. In a second series of experiments a fever of longer duration (each session lasting four hours), but of lesser intensity was induced. The number of sessions of heating varied in this series from four to fifteen, thus making a total duration of from sixteen to sixty hours of fever. The air temperature in the box was kept at $85^{\circ} \mathrm{F}$. to $95^{\circ} \mathrm{F}$. during these experiments. The temperature of the mice was taken half-hourly so that eight temperatures were recorded for each session.

At the end of the treatment the mice were killed by bleeding and their lymph glands, along with pieces of the spleen and liver on the one hand and their brains on the other hand, were tested for the presence of spirochætes by transference into the testes of separate rabbits. As a control mice which had been infected simultaneously with the heated mice, but had had no treatment, were tested in the same way. The inoculated rabbits were kept under observation for at least four months. In order to exclude 


\section{BRITISH JOURNAL OF VENEREAL DISEASES}

a latent infection in those rabbits which did not develop chancres, either their lymph glands were transferred into the testes of new rabbits with negative results or they were successfully reinoculated with known syphilitic material.

\section{Table I.-Treatment with Repeated Intense Heat-} INGS OF SHORT DURATION

\begin{tabular}{|c|c|c|c|c|c|c|c|c|c|c|}
\hline \multirow[b]{2}{*}{$\begin{array}{l}\text { No. of } \\
\text { Mouse. }\end{array}$} & \multirow[b]{2}{*}{ Strain. } & \multirow{2}{*}{$\begin{array}{c}\text { Duration } \\
\text { (in Days) of } \\
\text { Infection } \\
\text { before } \\
\text { beginning } \\
\text { of Treat- } \\
\text { ment. }\end{array}$} & \multirow{2}{*}{$\begin{array}{l}\text { Number } \\
\text { of } \\
\text { Heatings. }\end{array}$} & \multirow{2}{*}{$\begin{array}{c}\text { Total } \\
\text { Duration } \\
\text { (in } \\
\text { Hours) } \\
\text { of } \\
\text { Heating. }\end{array}$} & \multicolumn{4}{|c|}{ Number of Fever Peaks Reaching } & \multicolumn{2}{|c|}{$\begin{array}{c}\text { Result of } \\
\text { Inoculation of }\end{array}$} \\
\hline & & & & & $\begin{array}{r}42^{\circ} \mathrm{C} \\
107 \cdot 6^{\circ} \mathrm{F}\end{array}$ & $\mid \begin{array}{r}41^{\circ} \mathrm{C} \\
105^{\circ} 8^{\circ} \mathrm{F} \\
\text { and }\end{array}$ & $\begin{array}{l}40^{\circ} \mathrm{C} \text {. } \\
\text { I04 } \\
\text { more. }\end{array}$ & $39^{\circ} \mathrm{C}$. & $\begin{array}{l}\text { Lymph } \\
\text { Glands, } \\
\text { Spleen } \\
\text { and } \\
\text { Liver. }\end{array}$ & Brain. \\
\hline $\begin{array}{l}305 \\
309 \\
308 \\
306 \\
310\end{array}$ & $\begin{array}{c}\text { Nichols } \\
\text {,, } \\
\text {, } \\
\text {,, } \\
\text {,, }\end{array}$ & $\begin{array}{l}62 \\
, \\
, \\
, \\
,\end{array}$ & $\begin{array}{r}16 \\
\text { I } \\
7 \\
\\
\\
\\
\\
C\end{array}$ & $\begin{array}{l}4 \cdot 5 \\
4 \\
I \cdot 75 \\
O \\
O\end{array}$ & $\begin{array}{r}8 \\
2 \\
\mathrm{I} \\
\mathrm{N} \\
\mathrm{N}\end{array}$ & $\begin{array}{c}\frac{4}{5} \\
\mathrm{~T} \\
\mathrm{~T} \\
\mathrm{R}\end{array}$ & $\begin{array}{l}4 \\
7 \\
4 \\
\mathrm{O}^{\circ}\end{array}$ & $\begin{array}{l}\text { L } \\
\mathbf{L}\end{array}$ & $\begin{array}{l}0 \\
+6 \\
+7 \\
+7 \\
+7 \\
+7\end{array}$ & $\begin{array}{l}0 \\
+8 \\
+9 \\
+6 \\
+7\end{array}$ \\
\hline $\begin{array}{l}\text { I } 33 \\
\text { I34 } \\
\text { I47 } \\
\text { I46 } \\
\text { I48 }\end{array}$ & $\begin{array}{c}\text { Truffi } \\
,, \\
,, \\
,, \\
,,\end{array}$ & $\begin{array}{c}460 \\
, \\
, \\
, \\
,\end{array}$ & $\begin{array}{r}\text { I4 } \\
6 \\
4 \\
\\
\\
\\
\end{array}$ & $\begin{array}{c}3 \cdot 5 \\
I \cdot 5 \\
I \\
O \\
O\end{array}$ & $\underbrace{2}_{\mathrm{N}}-$ & 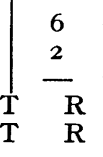 & $\begin{array}{l}5 \\
2 \\
2 \\
\mathrm{O}\end{array}$ & $\begin{array}{l}\text { L } \\
\text { L }\end{array}$ & $\begin{array}{r}d_{2} \dagger \\
+8 \\
+8 \\
+7 \\
+8\end{array}$ & $\begin{array}{l}0 \\
0 \\
0 \\
0 \\
0\end{array}$ \\
\hline $\begin{array}{l}356 \\
345 \\
348 \\
343 \\
344\end{array}$ & $\begin{array}{c}\text { Truffi } \\
\text {,, } \\
,, \\
\text {,, }\end{array}$ & $\begin{array}{c}\text { I04 } \\
\text {," } \\
\text {, } \\
\text {," }\end{array}$ & $\begin{array}{r}24 \\
14 \\
9 \\
\\
\end{array}$ & $\begin{array}{l}6 \cdot 25 \\
3 \cdot 5 \\
2 \cdot 25 \\
\mathrm{O} \\
\mathrm{O}\end{array}$ & $\begin{array}{l}5 \\
2 \\
N^{2} \\
N\end{array}$ & $\begin{array}{cc} & \mathrm{I}_{4} \\
& 9 \\
& 3 \\
\mathrm{~T} & \mathrm{R} \\
\mathrm{T} & \mathrm{R}\end{array}$ & $\begin{array}{l}5 \\
3 \\
4 \\
\mathrm{O}^{4} \\
\mathrm{O}\end{array}$ & $\underset{\mathrm{L}}{\mathrm{L}}$ & $\begin{array}{c}+11 \\
0 \\
+9 \\
+8 \\
+8\end{array}$ & $\begin{array}{c}+8 \\
0 \\
0 \\
0 \\
+0\end{array}$ \\
\hline
\end{tabular}

* Starting chancre after 6 weeks.

$\dagger$ Died after 2 weeks.

Each recorded peak of temperature corresponds to an exposure to heat for a quarter of an hour.

The results obtained in the first series of experiments with repeated intense heatings of short duration are summarised in Table I. It will be seen that only in a few instances was a sterilisation of the mice organs obtained. In those cases in which the total duration of fever was only a short one (one to two and a quarter hours) the results were uniformly negative. On the other hand, the results obtained with fever of longer duration were inconsistent. In two cases (mice 305 and 345) the organs became free of spirochætes after a total duration of fever (four and a half and three and a half hours) which proved 
insufficient in other cases (mice 309 and 356) ; the latter mouse even had as much as six and a quarter hours of fever. It will also be seen from the table that this inconsistency cannot be explained by differences in the height of the fever peaks reached.

For a strict comparison of the relative heat resistances between the spirochætes in the brain and in other organs only the first experiment on Nichols-mice can be considered (Table I.) because the incidence of brain invasion amongst the controls was irregular in the two other experiments with Truffi-mice. There is nothing in this experiment to suggest a different resistance to heat between spirochætes of the brain and other organs. Even the long duration of fever in mouse 356 did not suffice to sterilise the brain.

From the above results it follows that the treatment with short-although intense-heatings is unsatisfactory. The inconsistent results obtained in cases with a longer total duration of heat would suggest that the amount of fever given in these cases was at best somewhere near the lower limit of the minimal effective dose of heat.

Much better results were obtained in the second series of experiments in which the type of fever induced resembled more closely natural malarial fever. As will be seen from Table II. six out of nine mice were sterilised by this type of fever. But in this group also there were failures and a certain lack of consistency in the results. Whilst one might explain the negative results of fever therapy in mouse 490 and perhaps also in mouse 487 by the shorter duration of treatment as compared with the other mice, this argument does not hold good in the case of mouse 403 which had fifty-six hours of fever in all. In view of the few positive results obtained in the foregoing experiments with much shorter duration of heat it might seem surprising that in this second series of experiments thirteen, twenty-eight and even fifty-six hours of heat were insufficient to effect sterilisation. But this is not so if it be kept in mind that much lower fever peaks were used in this second series. An increase of the temperature above $106^{\circ} \mathrm{F}$. seems to be accompanied by a rapid reduction in the time necessary to kill the spirochætes.

When arranging the results obtained in the second series of experiments according to the number of halfhourly fever peaks of $104^{\circ} \mathrm{F}$. and more reached during the 
BRITISH JOURNAL OF VENEREAL DISEASES

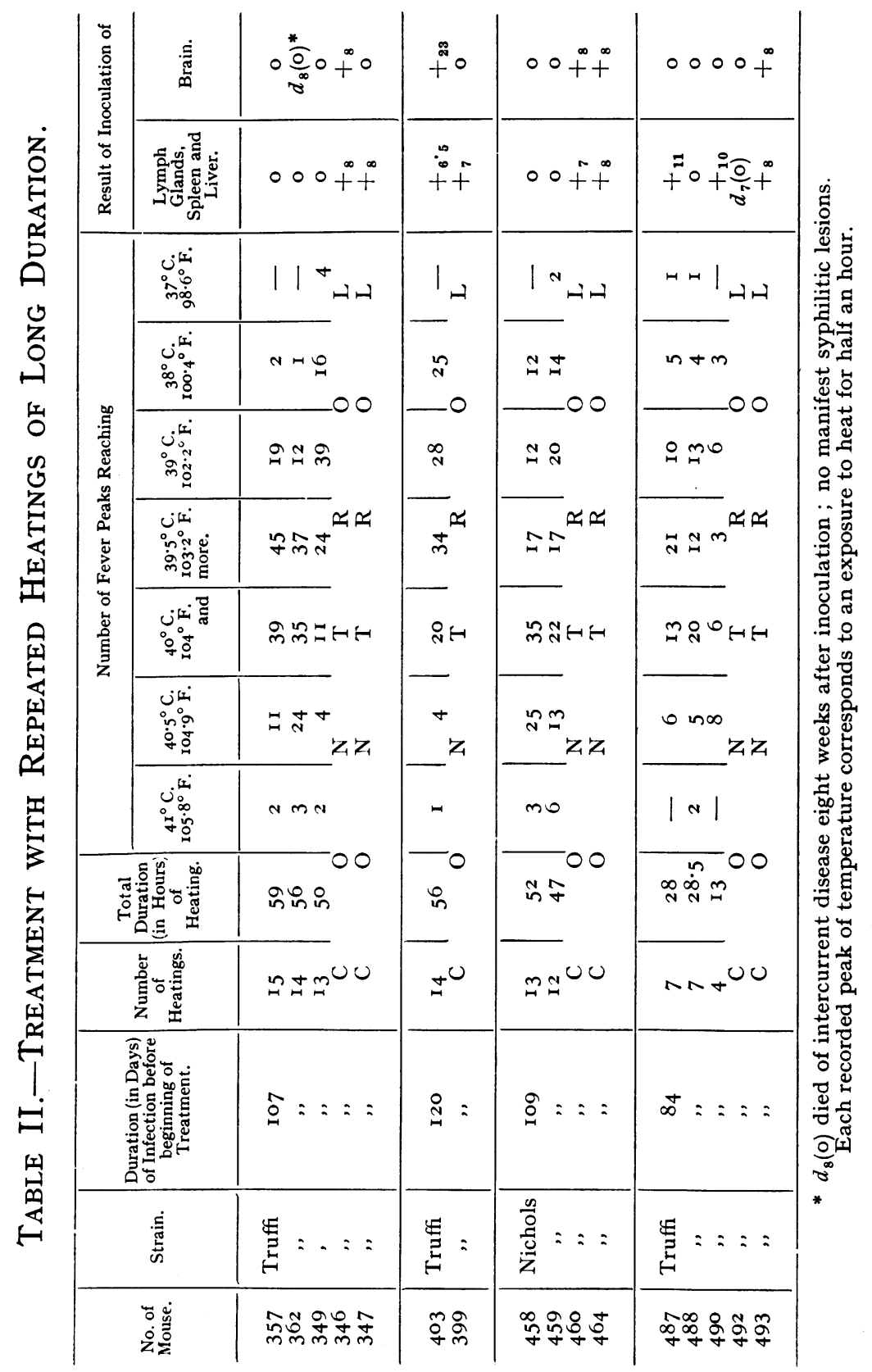

whole course of treatment (see Table III.) the negative result of mouse 403 might be explained by the relatively small number of such fever peaks. On the other hand, 


\section{INFLUENCE OF ARTIFICIALLY INDUCED FEVER}

mouse 349 with still fewer fever peaks above $104^{\circ} \mathrm{F}$. was sterilised. When reviewing all the results obtained in this series of experiments, it appears that at least twentyseven half-hourly fever peaks of $104^{\circ} \mathrm{F}$. or more were necessary to sterilise the organs of syphilitic mice. But such a figure must necessarily represent only an approximate estimate and might require some modification if experiments were carried out on a greater scale.

Table III.-Results OF the Second Series of EXPERIMENTS CLASSIFIED ACCORDING TO THE FEVER PEAKS OF IO $4^{\circ} \mathrm{F}$. OR MORE.

\begin{tabular}{l|c|c|c}
\hline & & \multicolumn{2}{|c}{ Result of Inoculation of } \\
\cline { 3 - 4 } Mouse No. & $\begin{array}{c}\text { Number of Fever Peaks } \\
\text { of } 104^{\circ} \text { F. or more. }\end{array}$ & $\begin{array}{c}\text { Lymph Glands, Spleen } \\
\text { and Liver. }\end{array}$ & Brain. \\
\hline 490 & I4 & + & 0 \\
349 & I7 & 0 & 0 \\
487 & I9 & + & 0 \\
403 & 25 & + & + \\
488 & 27 & 0 & 0 \\
459 & 41 & 0 & 0 \\
357 & 52 & 0 & 0 \\
362 & 62 & 0 & 0 \\
458 & 63 & 0 & 0 \\
\hline
\end{tabular}

In this series of experiments there was again no clear evidence of a different susceptibility to heat between the spirochætes in the brain and in other organs. A greater susceptibility of brain spirochætes might possibly be inferred from mice 487 and 490 , but the lack of uniformity in the finding of brain spirochætes amongst the control mice renders the significance of this observation very doubtful.

\section{Discussion}

The results obtained show that the spirochætes of mouse syphilis are far less susceptible to heat than those in external lesions of rabbit syphilis which, as quoted above, are readily destroyed by a temperature of $104^{\circ} \mathrm{F}$. acting for two hours. They seem to possess a heat resistance similar to that possessed by the spirochætes in the lymph glands of rabbits. The absence of any pronounced reaction of the tissues is common to both these 
types of spirochætes, and thus they may possess a priori a greater vitality than the spirochætes in open lesions which are exposed to an intense tissue reaction. This difference might become still more evident when the defence reactions already existent are further stimulated by heat.

But the experiments have also shown that even such resistant spirochætes might be influenced by heat, provided that the treatment were sufficient. The irregular and unsatisfactory results obtained in mice by Levaditi and his collaborators were-like the results of our first series of experiments-probably due to insufficient treatment. Moreover, a type of treatment which employs such short, although intense, bouts of fever, does not seem to be very efficient because, even though the total duration of treatment be high, the individual heatings are too short.

It must, however, be admitted that the intensity and total amount of heat does not seem to be the sole decisive factor in the fate of the spirochætes. There were some cases which remained positive in spite of what appeared to be a sufficient amount of treatment, and others in which the spirochætes disappeared although the amount of fever given was much less. Thus it is possible that besides the pure heat action there is some factor (constitutional or immunological) present in the individual which might influence the result of the treatment. But in spite of this the fact remains that a sufficiently long and intense course of treatment is the essential condition for a successful fever therapy.

\section{SUMMARY}

(I) Artificial fever was induced in syphilitic mice by exposure to hot air so as to imitate as closely as possible the course of malaria fever. With this type of fever spirochætes disappeared in two-thirds of the mice treated. The amount of fever treatment necessary for sterilisation of syphilitic mice was found to be thirteen and a half hours of a fever of $104^{\circ} \mathrm{F}$. or more.

(2) Treatment with a series of intense but short heatings (each lasting a quarter of an hour only) gave unsatisfactory results, only a quarter of the mice being freed from their spirochætes. 
(3) In some cases it appeared that an unknown factor (constitutional or immunological ?) modified the action of heat on the spirochætes.

(4) There is no evidence that the spirochætes in the brain of syphilis infected mice differ from those in other organs in their susceptibility to heat.

I wish to thank Professor Golla, Director of the Central Pathological Laboratory, L.C.C. Mental Hospitals Department, who rendered this work possible, and Dr. A. Davies, Director of the Devonport Laboratory, Seamen's Hospital, for affording me hospitality at his laboratory.

\section{REFERENCES}

Bessemans, A., de Potter, F., and Hacquert, R. (I928) : C.R. Soc. Biol., 99, I6ro, I6r3.

Bessemans, A., de Potter, F., and Hacquert, R. (I929) : ibid., 100,$757 ; 101,163$.

IDEM (I936) : Arch. Derm. Syph., 8, 46.

IDEM and DE MOOR, A. (I937): Derm. Zeitschr., 75, 57.

Carpenter, C. M., Boak, R. A., and Warren, S. L. (I932): J. Exp. Med., 56, 75I.

DATTNER, B. (I933): Moderne Therapie der Neurosyphilis, Wien, Maudrich, 287.

Kolmer, J. A., and Rule, A. M. (I933) : Arch. Derm. Syph., 27, 660. Levaditi, C., and DE Rothschild, H. (I934): Ann. Inst. Past., 52, 23.

Richet fils, C., and Dublineau, N. (I932): Bull. Acad. Med., Paris, 108, I682.

Schamberg, J. F., and Rule, A. M. (I927) : J. Am. Med. Ass., 88, I2I7.

Weichbrodt, R., and Jahnel, F. (I9I9) : Deutsch. med. Wschr., 45, 483. 